\title{
A randomized controlled trial with everolimus for IQ and autism in tuberous sclerosis complex
}

Iris E. Overwater, MD, PhD, André B. Rietman, MSc, Sabine E. Mous, PhD, Karen Bindels-de Heus, MD, Dimitris Rizopoulos, PhD, Leontine W. ten Hoopen, MD, Thijs van der Vaart, MD, PhD, Floor E. Jansen, MD, PhD, Ype Elgersma, PhD, Henriette A. Moll, MD, PhD, and Marie-Claire Y. de Wit, MD, PhD, on behalf of the ENCORE Expertise Centre for Neurodevelopmental Disorders

Neurology ${ }^{\circledR}$ 2019;93:e200-e209. doi:10.1212/WNL.0000000000007749

\section{Abstract}

\section{Objective}

To investigate whether mammalian target of rapamycin inhibitor everolimus can improve intellectual disability, autism, and other neuropsychological deficits in children with tuberous sclerosis complex (TSC).

\section{Methods}

In this 12-month, randomized, double-blind, placebo-controlled trial, we attempted to enroll 60 children with TSC and IQ $<80$, learning disability, special schooling, or autism, aged 4-17 years, without intractable seizures to be assigned to receive everolimus or placebo. Everolimus was titrated to blood trough levels of 5-10 ng/mL. Primary outcome was full-scale IQ; secondary outcomes included autism, neuropsychological functioning, and behavioral problems.

\section{Results}

Thirty-two children with TSC were randomized. Intention-to-treat analysis showed no benefit of everolimus on full-scale IQ (treatment effect -5.6 IQ points, 95\% confidence interval -12.3 to 1.0$)$. No effect was found on secondary outcomes, including autism and neuropsychological functioning, and questionnaires examining behavioral problems, social functioning, communication skills, executive functioning, sleep, quality of life, and sensory processing. All patients had adverse events. Two patients on everolimus and 2 patients on placebo discontinued treatment due to adverse events.

\section{Conclusions}

Everolimus did not improve cognitive functioning, autism, or neuropsychological deficits in children with TSC. The use of everolimus in children with TSC with the aim of improving cognitive function and behavior should not be encouraged in this age group.

\section{Clinicaltrials.gov identifier \\ NCT01730209.}

\section{Classification of evidence}

This study provides Class I evidence that for children with TSC, everolimus does not improve intellectual disability, autism, behavioral problems, or other neuropsychological deficits.

\author{
Correspondence \\ Dr. de Wit \\ m.c.y.dewit@erasmusmc.nl \\ or Dr. Moll \\ h.a.moll@erasmusmc.nl \\ or Dr. Elgersma \\ y.elgersma@erasmusmc.nl
}

\section{RELATED ARTICLE}

\section{Editorial}

Everolimus for cognition/ autism in children with tuberous sclerosis complex: Definitive outcomes deferred

Page 51

\section{MORE ONLINE}

\section{$\rightarrow$ Class of Evidence}

Criteria for rating therapeutic and diagnostic studies

NPub.org/coe

\footnotetext{
From the ENCORE Expertise Centre for Neurodevelopmental Disorders (I.E.O., A.B.R., S.E.M., K.B.-d.H., L.W.t.H., T.v.d.V., Y.E., H.A.M., M.-C.Y.d.W.) and Departments of Neurology (I.E.O., T.v.d.V., M.-C.Y.d.W.), Child and Adolescent Psychiatry and Psychology (A.B.R., S.E.M., L.W.t.H.), and Pediatrics (K.B.-d.H., H.A.M.), Erasmus MC-Sophia Children's Hospital; Departments of Biostatistics (D.R.) and Neuroscience (Y.E.), Erasmus MC, Rotterdam; and Department of Child Neurology (F.E.J.), Brain Centre Rudolf Magnus, University Medical Centre Utrecht, the Netherlands.

Go to Neurology.org/N for full disclosures. Funding information and disclosures deemed relevant by the authors, if any, are provided at the end of the article.
} 


\section{Glossary}

ADOS = Autism Diagnostic Observation Schedule; Beery VMI $=$ Beery-Buktenica Developmental Test of Visual-Motor Integration; CANTAB = Cambridge Neuropsychological Test Automated Battery; $\mathrm{CBCL}=$ Child Behavior Checklist; $\mathbf{C I}=$ confidence interval; DSMB = data safety monitoring board; IQR = interquartile range; $\mathbf{m T O R}=$ mammalian target of rapamycin; SDSC $=$ Scale for Children; SRS $=$ Social Responsiveness Scale; TRF $=$ Teacher Report Form; TSC $=$ tuberous sclerosis complex; WISC-III-NL = Wechsler Intelligence Scale for Children; WPPSI-III-NL = Wechsler Preschool and Primary Scale of Intelligence.

Mutations in the TSC1 or TSC2 genes cause constitutive and hyperactivation of mammalian target of rapamycin (mTOR). This is thought to lead to the spectrum of hamartoma growth in tuberous sclerosis complex (TSC). ${ }^{1}$ In the brain, cortical malformations result in epilepsy, intellectual disability, autism, or behavioral difficulties in most patients. Currently only supportive care and early seizure control contribute to a better outcome.

The mTOR inhibitor everolimus reduces SEGA or angiomyolipoma volume and seizure frequency in patients with TSC. $^{2-4}$ Better epilepsy control can improve cognitive outcome. ${ }^{4-6}$ A positive effect of mTOR inhibitors on cognition and behavior in absence of epilepsy has been shown in animal models. ${ }^{7-10}$ An open-label study examining sirolimus in TSC-associated lymphangioleiomyomatosis found recall memory improved in 7 of 8 patients. ${ }^{11}$ A case series reported improved social interaction in 6 patients. ${ }^{12}$ This sparked hope for positive effects on cognition and behavior. However, a recent trial investigating 6 months everolimus treatment in 47 patients found no effect on behavior and development. ${ }^{13} \mathrm{~A}$ randomized trial investigating intractable epilepsy in 23 children with TSC found no effect of sirolimus on neuropsychological outcomes, ${ }^{14}$ nor did a study investigating everolimus for SEGA in 24 patients. ${ }^{15}$ These studies included limited numbers of patients, and IQ was not a primary outcome, precluding definite conclusions. mTOR hyperactivation has also been implicated in idiopathic autism, sparking a broader interest in mTOR inhibition.

We report on a randomized, placebo-controlled trial examining the effect of 12 months treatment with everolimus on IQ neuropsychological deficits, and autism in children with TSC.

\section{Methods}

\section{Participants}

Patients were eligible for inclusion if they had a definite diagnosis of TSC based on the 2012 International Tuberous Sclerosis Complex Diagnostic Criteria, ${ }^{16}$ if they were between 4 and 17 years old, and if they had an IQ under 80 or learning disability or special schooling or autism spectrum disorder. Patients were excluded from trial participation if their developmental level was below 3.5 years, if they had more than one epileptic seizure per week, if they had severe liver or kidney dysfunction, or if they were diagnosed with other somatic conditions that required treatment. Patients were also excluded if they had had prior treatment with an mTOR inhibitor.

Data were collected at the ENCORE TSC expertise center at the Erasmus MC-Sophia Children's Hospital in Rotterdam, the Netherlands. Oral and written informed consent was obtained from parents of participating children before randomization, and assent was given by children over 11 years old if they were cognitively able.

\section{Standard protocol approvals, registrations, and patient consents}

The trial protocol was approved by the national and Erasmus MC institutional ethics review boards, registration number MEC-2011-483. The trial was performed in agreement with the Declaration of Helsinki (2008) and Good Clinical Practice guidelines. This trial is registered as NCT01730209 at clinicaltrials.gov. An online version of the trial protocol is available at the Erasmus MC website (erasmusmc.nl/encore/ Poliklinieken/tubereuze-sclerose-complex/wetenschondtsc/ klinondtsc/onderzoeksprotocolC1/?view=active).

\section{Randomization and masking}

All participants were randomly assigned (1:1) to receive everolimus or placebo using a permuted-block (block size 4) computer-generated randomization list provided by the Erasmus MC Department of Biostatistics. Randomization was stratified according to age (4-8 years and 9-17 years) and was carried out by the Erasmus MC pharmacy concealing allocation sequence from researchers. All researchers, physicians, parents, and participants were masked to treatment.

\section{Study design}

After randomization, patients received masked everolimus or placebo treatment for 12 months. A sample size of 60 participants was calculated to reach $80 \%$ power with a 2 -sided $\alpha$ of 0.05 to show a minimal treatment effect on the primary outcome of $0.75 \mathrm{SD}$, which was considered a clinically relevant change.

Patients were contacted after 1 week, 2 weeks, 1 month, and monthly thereafter. At every trial contact, seizure frequency and adverse events were assessed, according to the WHO adverse reaction terminology and the National Cancer Institute common terminology criteria for adverse events version 3.0. Blood was drawn for safety and trough levels at the visits 1 week, 2 weeks, 1 month, 3 months, 6 months, 9 months, and 12 months after the 
start of treatment, and 2 weeks after an additional dose change. All trial contacts in between these visits were by telephone.

Placebo and everolimus tablets of $2.5 \mathrm{mg}$ were identical in size, appearance, taste, and odor. Participants received a starting dose of everolimus based on their body surface area, corrected for use of drugs influencing the CYP3A4 enzyme. All other drugs that participants were already taking were continued. Everolimus dose was titrated to trough levels between 5 and $10 \mathrm{ng} / \mathrm{mL}$. To ensure masking, the Erasmus MC pharmacy analyzed all blood samples for trough levels. Patients taking placebo were given simulated trough levels, also requiring occasional dose changes. Administration of everolimus or placebo was once daily, at a fixed time during the day. Tablets were ingested with water. In case of adverse events of grade 2 or higher, everolimus was discontinued until the adverse event subsided or reached grade 1, and was restarted at the last dose without adverse events.

A data safety monitoring board (DSMB) was installed before trial start, consisting of a pediatrician specialized in children with genetic disabilities, a pediatrician specialized in infections, and a statistician. The DSMB was provided biannually with safety reports. The DSMB and Novartis AG were notified within 24 hours in case of a serious event. The DSMB had authority to unmask a participant or to stop the trial in case of safety concerns.

\section{Outcome measures}

All outcomes were assessed using the same version of an assessment at baseline and after 12 months for all patients, independent of their age. Primary outcome was change in full-scale IQ measured at baseline and after 12 months of trial participation using the Wechsler Preschool and Primary Scale of Intelligence (WPPSI-III-NL) ${ }^{17}$ or the Wechsler Intelligence Scale for Children (WISC-III-NL). ${ }^{18}$ Scores below the range of the assessment were calculated by hand.

Secondary outcomes measured at baseline and after 12 months of study participation included change in performance IQ and verbal IQ as measured by the Wechsler scales. Other secondary outcomes included change in autistic features measured by the Autism Diagnostic Observation Schedule (ADOS), visualmotor integration measured by the Beery-Buktenica Developmental Test of Visual-Motor Integration (Beery VMI), ${ }^{19}$ and fine motor skills by the Grooved Pegboard. Additional secondary outcomes were assessed with the proxy reports of parents, using questionnaires examining (1) behavioral and emotional problems (Child Behavior Checklist [CBCL]), (2) social and communication skills (Social Responsiveness Scale $[\mathrm{SRS}]^{20}$ and Dutch Children's Communication Checklist [CCC-2-NL]), ${ }^{21}$ (3) sleep quality (Sleep Disturbance Scale for Children [SDSC]), ${ }^{22}$ (4) sensory processing (Short Sensory Profile), ${ }^{23}$ and (5) quality of life (Child Health QuestionnaireParent Form [CHQ-PF50]). ${ }^{24}$ Behavioral and emotional problems at school were assessed by teachers of the participants using the Teacher Report Form (TRF). ${ }^{25}$ Other outcome measures included frequency of epileptic seizures and safety of everolimus use.

Two instruments were used at baseline, after 6 months, and after 12 months: the Cambridge Neuropsychological Test Automated Battery (CANTAB) and the parental rating scale Behavior Rating Inventory of Executive Functioning. ${ }^{26}$ Change in information processing speed, working memory, planning, and attention were examined using the Motor Screening, Big/Little Circle, Stockings of Cambridge, Spatial Span, Spatial Working Memory, and Reaction Time subtests of the CANTAB.

\section{Classification of evidence}

Our primary research question was whether everolimus treatment could improve intellectual disability, autism, behavioral problems, and other neuropsychological deficits in children with TSC. This interventional study provides Class I evidence that 12 months of everolimus treatment could not improve full-scale IQ (treatment effect -5.6 IQ points, $p=0.095$ ), autism, behavioral problems, or other neuropsychological deficits. Though the sample size of our trial is limited, the observed treatment effect favors the placebo group over the everolimus group, and larger samples as originally intended would not be able to show a positive treatment effect. A beneficial effect of everolimus in very young children is not ruled out.

\section{Statistical analyses}

Data from all randomized patients were included in all analyses (intention-to-treat). Endpoint of the trial was defined as 12 months after start of treatment, regardless of completing 12 months of treatment. Baseline categorical data were analyzed using $\chi^{2}$ tests; baseline numerical data were analyzed using independent samples $t$ tests. The primary and all secondary neuropsychological outcomes were analyzed using a linear regression model, after verifying all assumptions for linear regression. Independent variables included baseline scores, as well as whether the patient was treated with placebo or everolimus. For every outcome measure, test versions were chosen according to age and developmental level of the patient. This caused some patients being assessed using tests without scaled scores for their calendar age. For this reason, raw scores rather than scaled scores were used in the analyses of the Beery-VMI, Grooved Pegboard, SRS, and SDSC, and IQ was calculated by hand for children assessed by WPPSI-III-NL instead of WISCIII-NL. Raw scores for CBCL and TRF were used because standard scores for these questionnaires are truncated. For analyses of raw scores, the age at baseline was included as an independent variable in the linear regression model.

Outcomes examined at 0,6 , and 12 months were first assessed for possible differences between 0 and 12 months. In the case of a statistical difference, analysis was expanded to investigate any statistical differences between 0 and 6 months and between 6 and 12 months. 
All data were analyzed using IBM SPSS statistics version 21 (SPSS Inc., Chicago, IL).

\section{Data sharing statement}

Individual de-identified participant data from all trial outcomes and the statistical analysis plan will be shared. All participant data will be saved for 15 years after the last patient concluded the last visit (April 2016). Data will be made available to researchers providing a methodologically sound proposal, who will use these data only for this proposal. Interested researchers can inquire at kinderneurologie@erasmusmc.nl. To gain access, data requestors will need to sign a data access agreement.

\section{Results}

Between November 21, 2012, and April 28, 2015, 32 patients were randomly assigned to receive everolimus $(n=15)$ or placebo treatment $(n=17)$ (figure 1). We aimed to include 60 patients but due to low inclusion rates, we stopped inclusion prematurely without an interim analysis, with consent of the local ethics committee and the DSMB. Baseline characteristics were well-balanced between randomized groups (table 1). Median baseline intelligence was 60 (range 25-107) in patients receiving placebo and 71 (range 22-102) in patients receiving everolimus.

Twelve months of everolimus treatment had no effect on fullscale IQ compared to placebo (treatment effect -5.6 IQ points, $95 \%$ confidence interval [CI] -12.3 to $1.0, p=0.095$ ) (figure 2). This lack of benefit from everolimus was similar when analyzing performance IQ (treatment effect -6.4 IQ points, $95 \% \mathrm{CI}-14.1$ to $1.3, p=0.100$ ) and verbal IQ (treatment effect -2.9 IQ points, $95 \% \mathrm{CI}-10.9$ to $5.2, p=$ 0.471 ). Analysis of autism features measured by the ADOS showed no benefit of everolimus (treatment effect $-0.6,95 \%$ CI -2.0 to $0.9, p=0.426$ ). At baseline, autism spectrum features were found in $11 / 17$ children $(65 \%)$ treated with placebo, while $12 / 17$ children (71\%) showed such features after 12 months of placebo treatment. In children treated with everolimus, 6/15 (40\%) showed autism spectrum features at baseline, while after 12 months of treatment such features were present in 7/15 (47\%). Everolimus had no effect on visual motor integration as measured by Beery-VMI (treatment effect $-1.7,95 \%$ CI -4.2 to $0.9, p=0.190$ ), fine motor skills as measured by the Grooved Pegboard (treatment effect $-13.3,95 \%$ CI -45.1 to $18.5, p=0.397$ ), or memory and executive functioning as measured by the CANTAB tasks

Figure 1 Trial profile

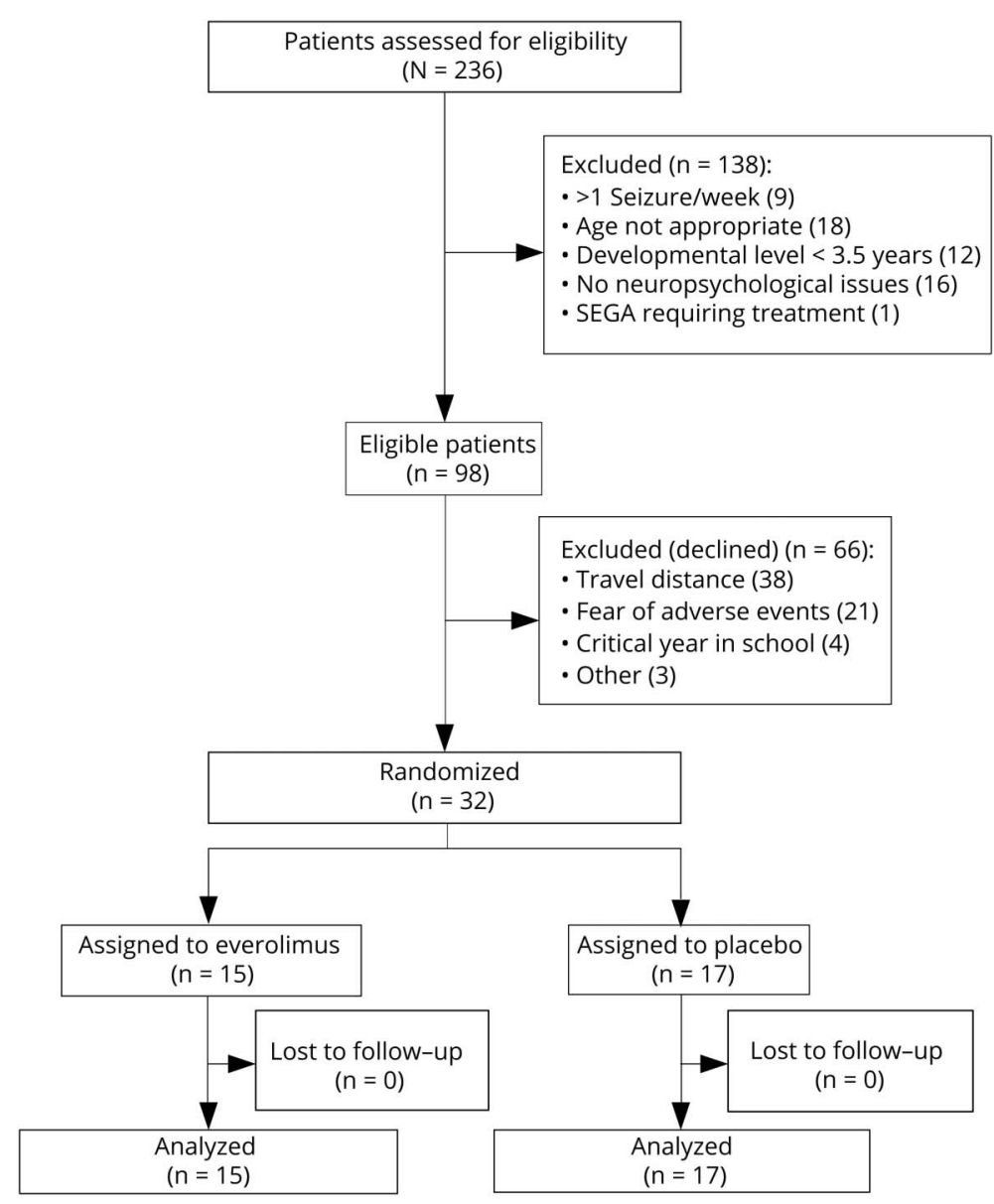


Table 1 Baseline characteristics of included children

\begin{tabular}{|c|c|c|}
\hline & Placebo $(n=17)$ & Everolimus $(n=15)$ \\
\hline Male, n (\%) & $6(35)$ & $10(67)$ \\
\hline Age at inclusion, $y$, median (IQR) & $11.5(6.9-14.9)$ & $12.2(8.5-14.7)$ \\
\hline Mutation TSC1/TSC2/NMI, n (\%) & $4 / 11 / 2(24 / 64 / 12)$ & $3 / 10 / 2(20 / 67 / 13)$ \\
\hline History of epilepsy, n (\%) & $15(88)$ & $10(67)$ \\
\hline Seizures at inclusion, $\mathrm{n}(\%)$ & $8(47)$ & $6(40)$ \\
\hline History of infantile spasms, $n$ (\%) & $5(29)$ & $2(13)$ \\
\hline Patients taking AEDs at baseline, $\mathrm{n}(\%)$ & $12(71)$ & $7(47)$ \\
\hline Baseline IQ, median (IQR) & $60(48-79)$ & $71(60-91)$ \\
\hline
\end{tabular}

Abbreviations: $\mathrm{AED}=$ antiepileptic drugs; $\mathrm{IQR}$ = interquartile range; $\mathrm{NMI}=$ no mutation identified.

No differences were found between the groups in any of these characteristics $(p>0.1)$.

(table 2). No treatment effect was found on questionnaires examining behavioral and emotional problems at home, social functioning, communication skills, executive functioning, sleep, quality of life, sensory processing, or emotional and behavioral problems at school (table 3).

\section{Epilepsy}

As shown in table 1 , a total of 25 patients ( $78 \%$ ) had a history of epilepsy and 14 patients (44\%) still had epilepsy at baseline with a low seizure frequency. In the group taking everolimus, no seizures occurred after long periods of seizure

Figure $\mathbf{2}$ Treatment effect of everolimus vs placebo on neuropsychological outcomes

A

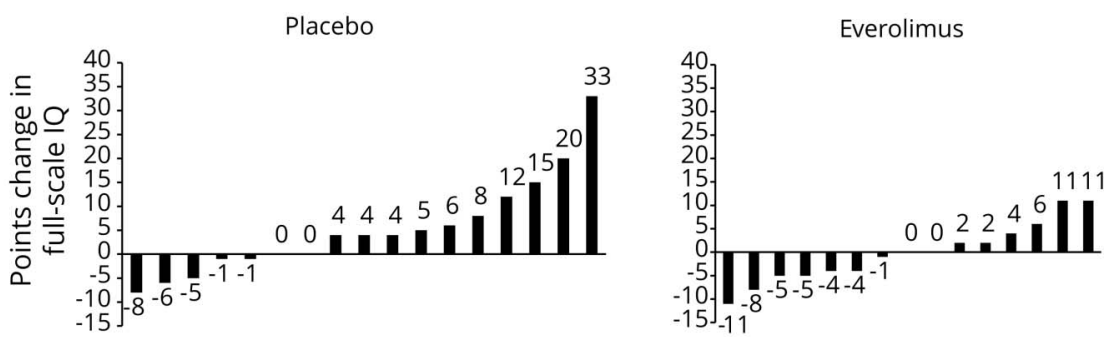

B

Full-scale IQ

Performance IQ

Verbal IQ

Visual-motor integration

Fine motor skills

Behavioral and emotional problems

Social dysfunctioning

Communication skills

Executive functioning

Sleep quality

Quality of life

Sensory processing

Behavioral and emotional problems at school

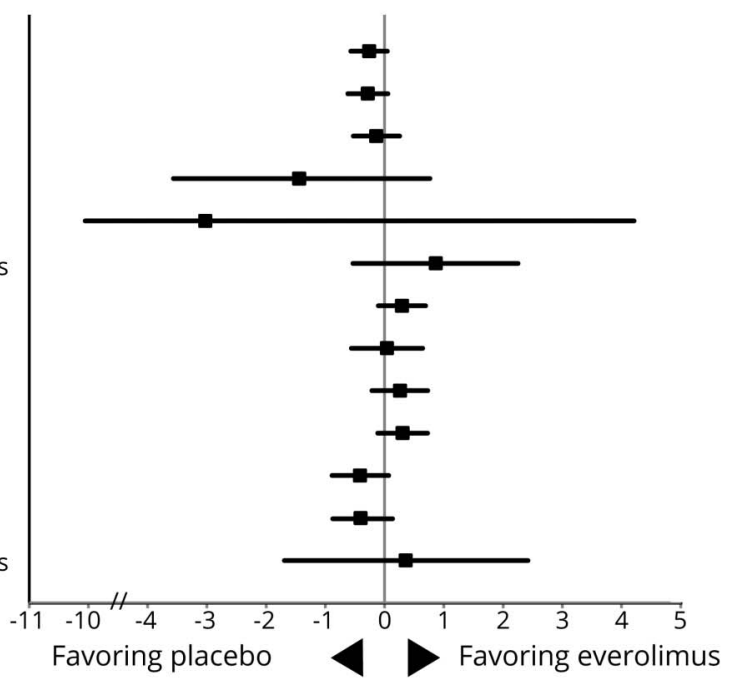

(A) Waterfall plots of points change in full-scale IQ for patients taking placebo or everolimus. (B) Standardized treatment effect of primary and secondary outcome measures, converted to SD difference with corresponding 95\% confidence interval. Visual-motor integration was measured by Beery-Buktenica Developmental Test of Visual-Motor Integration; fine motor skills were measured by Grooved Pegboard. For all other outcomes, corresponding assessment methods can be found in table 3 and Methods. 
Table 2 Cambridge Neuropsychological Test Automated Battery (CANTAB) subtest analyses

\begin{tabular}{|c|c|c|c|c|c|}
\hline CANTAB subtest & $\begin{array}{l}\text { Patients } \\
\text { analyzed }\end{array}$ & $\begin{array}{l}\text { Treatment effect everolimus vs } \\
\text { placebo }\end{array}$ & $\begin{array}{l}95 \% \mathrm{Cl} \text { lower } \\
\text { bound }\end{array}$ & $\begin{array}{l}95 \% \mathrm{Cl} \text { upper } \\
\text { bound }\end{array}$ & $\begin{array}{l}p \\
\text { Value }\end{array}$ \\
\hline MOT motor screening & 32 & -232.6 & -542.9 & 77.7 & 0.135 \\
\hline BLC set-shifting & 30 & 1.0 & -1.5 & 3.5 & 0.414 \\
\hline RTI movement time & 21 & 19.6 & -252.7 & 291.9 & 0.881 \\
\hline RTI reaction time & 21 & 68.4 & -51.6 & 188.4 & 0.246 \\
\hline SOC initial thinking time & 23 & 530.2 & $-1,507.8$ & $2,568.2$ & 0.591 \\
\hline SOC subsequent thinking time & 23 & 282.3 & -473.7 & $1,038.3$ & 0.443 \\
\hline SOC minimum moves & 21 & 0.1 & -1.7 & 1.8 & 0.915 \\
\hline $\begin{array}{l}\text { Short Sensory Profile span } \\
\text { length }\end{array}$ & 29 & 0.1 & -0.8 & 0.9 & 0.866 \\
\hline SWM between errors & 29 & -8.9 & -27.1 & 9.3 & 0.326 \\
\hline SWM strategy & 29 & 0.1 & -3.4 & 3.7 & 0.946 \\
\hline
\end{tabular}

Abbreviation: $\mathrm{Cl}=$ confidence interval.

Treatment effect values are unstandardized $\beta$ s.

freedom. As we purposely included patients with wellcontrolled epilepsy (no or only incidental seizures), we could not analyze changes in seizure frequency or epilepsy severity.

\section{Everolimus intake}

Median everolimus trough level after 6 months of trial participation was $4.7 \mathrm{ng} / \mathrm{mL}$ (interquartile range [IQR] 3.9-5.3 $\mathrm{ng} / \mathrm{mL}$ ); median trough level after 12 months was $4 \mathrm{ng} / \mathrm{mL}$ (IQR 3.8-6 ng/mL). Median everolimus dose was $5 \mathrm{mg}$ (range $1.25-10 \mathrm{mg}$ ). Of the 13 patients receiving everolimus, 9 patients (69\%) interrupted treatment due to adverse events, with a median of 2 interruptions per patient, and a median duration of 8 days. Everolimus was taken on $94 \%$ of all study days. Of the 15 patients receiving placebo and who completed the treatment period, 4 (27\%) interrupted treatment due to adverse events, with a median of 2 episodes, and 2 days per interruption. Placebo was taken on $99 \%$ of all trial days.

\section{Adverse events}

All patients experienced adverse events (table 4). No grade 3 or 4 adverse events were reported. Infections were more frequent in patients treated with everolimus. One patient

Table 3 Results from all questionnaires

\begin{tabular}{|c|c|c|c|}
\hline Questionnaire & Feature examined & $\begin{array}{l}\text { Treatment effect everolimus vs placebo } \\
(95 \% \mathrm{Cl})\end{array}$ & $\begin{array}{l}p \\
\text { Value }\end{array}$ \\
\hline Child Behavior Checklist & Behavioral and emotional problems & $8.1(-5.0$ to 21.1$)$ & 0.215 \\
\hline Social Responsiveness Scale & $\begin{array}{l}\text { Social dysfunctioning and autistic } \\
\text { features }\end{array}$ & $9.4(-3.4$ to 22.2$)$ & 0.144 \\
\hline $\begin{array}{l}\text { Dutch Children's Communication Checklist } \\
\text { (CCC-2-NL) }\end{array}$ & Communication skills & $0.8(-10.7$ to 12.3$)$ & 0.888 \\
\hline $\begin{array}{l}\text { Behavior Rating Inventory of Executive } \\
\text { Functioning }\end{array}$ & Executive functioning & $2.9(-2.4$ to 8.1$)$ & 0.271 \\
\hline Sleep Disturbance Scale for Children & Sleep quality & $3.4(-1.3$ to 8.1$)$ & 0.143 \\
\hline $\begin{array}{l}\text { Child Health Questionnaire-Parent Form (CHQ- } \\
\text { PF50) }\end{array}$ & Quality of life & $-4.1(-8.8$ to 0.7$)$ & 0.091 \\
\hline Short Sensory Profile & Sensory processing & $-0.6(-1.3$ to 0.2$)$ & 0.141 \\
\hline Teacher Report Form & $\begin{array}{l}\text { Behavioral and emotional problems at } \\
\text { school }\end{array}$ & $3.1(-14.6$ to 20.9$)$ & 0.715 \\
\hline
\end{tabular}

Treatment effect values are unstandardized $\beta$ s. 
Table 4 All adverse events registered during trial participation

\begin{tabular}{|c|c|c|}
\hline Event & $\begin{array}{l}\text { Placebo } \\
(n=17)\end{array}$ & $\begin{array}{l}\text { Everolimus } \\
(n=15)\end{array}$ \\
\hline Gastrointestinal & $12(71)$ & $14(93)$ \\
\hline Upper respiratory tract infection & $13(76)$ & $12(80)$ \\
\hline Aphthous ulcers & $7(41)$ & $12(80)$ \\
\hline Acne-like skin lesions & $9(53)$ & $10(67)$ \\
\hline Headache & $8(47)$ & $9(60)$ \\
\hline Other infection & $5(29)$ & $9(60)$ \\
\hline Fatigue & $8(47)$ & $8(53)$ \\
\hline Injury due to accident & $6(35)$ & $5(33)$ \\
\hline Eczema & $2(12)$ & $4(27)$ \\
\hline Hemorrhagic disorders & $4(24)$ & $2(13)$ \\
\hline Fever of unknown origin & $1(6)$ & $2(13)$ \\
\hline Edema & $1(6)$ & $2(13)$ \\
\hline Hyperventilation & $1(6)$ & $2(13)$ \\
\hline Anorexia & 0 & $2(13)$ \\
\hline Amenorrhea & 0 & $1(7)$ \\
\hline $\begin{array}{l}\text { Worsening of psychiatric } \\
\text { symptoms }\end{array}$ & 0 & $1(7)$ \\
\hline Hypertension & 0 & $1(7)$ \\
\hline Pneumonia & 0 & $1(7)$ \\
\hline Dental cavities & 0 & $1(7)$ \\
\hline Vertigo & $2(12)$ & 0 \\
\hline Osgood-Schlatter disease & $1(6)$ & 0 \\
\hline
\end{tabular}

Values depict $\mathrm{n}(\%)$ of children who experienced an adverse event. All adverse events were grade 1 or 2 . Gastrointestinal adverse events included diarrhea, nausea, vomiting, and constipation. Aphthous ulcers also include stomatitis and mouth ulcers. Other infections included varicella-zoster, measles, and fungal infections. Aphthous ulcers occurred more often in the everolimus group ( $p=0.03$ ); there was no relationship with dose or blood level. For all other adverse events, differences between the everolimus and placebo group were not significant.

taking everolimus had pneumonia, without requiring hospitalization. Aphthous ulcers occurred in 12 patients (80\%) taking everolimus and in 7 patients $(41 \%)$ taking placebo. Of the 4 patients taking everolimus who had had their menarche at baseline, one patient experienced 2 episodes of amenorrhea, both lasting 5 months. Adverse events resulted in discontinuation of treatment in 4 patients, of whom 2 received everolimus treatment. In the patients taking placebo, in one patient reason for discontinuation was an epileptic seizure after being seizure-free for 6 years, and in the other patient worsening of fatigue. Reasons for discontinuation of everolimus treatment included worsening of psychiatric symptoms in both patients, most importantly depression and aggression.

\section{Discussion}

This randomized, double-blind, placebo-controlled trial of everolimus for intelligence, neuropsychological deficits, and autism in children with TSC showed no significant improvement by everolimus treatment on full-scale IQ (treatment effect -5.6 IQ points, $95 \%$ CI -12.3 to $1.0, p=0.095$ ). Also, no effect was found on any secondary outcome measure, including performance IQ, verbal IQ, autism as measured by $\mathrm{ADOS}$, and CANTAB tasks examining executive functioning.

Researchers, parents, and patients held much hope for a beneficial effect of everolimus on cognitive function and autism features, as preclinical studies showed significant positive effects on behavior and cognition, and clinical studies showed that everolimus reduces TSC-related tumor growth and seizure frequency in patients. However, our trial shows that, in patients with TSC aged 6.9-14.9 years, everolimus used for 12 months has no beneficial effect on intelligence or autism. These results are in line with a recently published trial that found no benefit of 6 months everolimus treatment in 47 patients with TSC aged $6-21$ years on behavior. ${ }^{13}$ Since at the time of trial design no previous clinical trials in patients with TSC had been reported with preregistered cognitive assessments as primary outcome, the outcome measures selected in our trial were based on neuropsychological issues reported in literature, and issues signaled by psychiatrists and psychologists with experience in treating patients with TSC. In addition, we used a comprehensive assessment that captures overall functioning of the patients. We chose full-scale IQ as our primary outcome measure because we believe this to be the most clinically relevant outcome for the cognitive functioning of children, as it is a stable outcome measure that covers a broad spectrum of functioning and is predictive of educational success. It might be that full-scale IQ is too broad of a measure to be changed by treatment with a drug for a period of 12 months, so we expanded the assessment battery with a broad range of neuropsychological tests and questionnaires as secondary outcomes. We show no clear sign of improvement in executive functioning, memory, attention, behavior, or autism features. A clinically relevant improvement in cognitive or behavioral measures that was not directly assessed in our trial is unlikely. Due to the nature of the tests, we excluded children under the age of 4 , and it might be that in older children IQ is less plastic. With our data, we cannot specifically exclude a positive effect in younger patients.

Our aim was to include 60 patients with TSC to show a clinically relevant treatment effect of $0.75 \mathrm{SD}$ on our primary outcome. Inclusion rate slowed down considerably (we included 2 patients in the last year of the trial), and we decided to discontinue after inclusion of 32 participants. As shown in figure 1, we assessed 98 patients who were eligible for inclusion. Sixty-six (67\%) declined participation, mainly due to large travel distance or fear of adverse events. Although we would have preferred to have reached our inclusion goal, our results are robust and show no positive effect. Considering the 
high test-retest reliability of our primary outcome measure, we can safely conclude that including 60 patients would not have resulted in a clinically relevant positive effect of everolimus in this age group.

Children randomized to receive everolimus treatment were less likely to have had epilepsy and had slightly higher baseline IQ values (not significant). It could be argued that patients with higher baseline IQ values are less likely to improve. However, it could also be argued that, in children with active epilepsy, it might be more difficult to treat intellectual disability as this is known to be influenced by regular seizures. Our data do not confirm either of these 2 possibilities (not shown).

We decided on a long treatment duration of 12 months. A full year of treatment is a challenge in a clinical trial, but dysfunctional neuropsychological patterns have developed in patients for many years, and the recovery of changes caused by increased mTOR activation is most likely a long-term process. Throughout the trial, we monitored trough levels and compliance. Target trough levels were chosen based on effectiveness in previous trials. ${ }^{3}$ The recent registration trial on everolimus for intractable TSC-related epilepsy suggested higher trough levels may be more effective for seizures, and this could also be true for cognition and behavior. ${ }^{4}$ However, also in that trial, higher trough levels were difficult to achieve due to adverse events and interactions between drugs. The optimal dose for a possible treatment of cognition and behavior has yet to be defined.

Considering our results, if everolimus could have a positive effect on cognitive and behavioral outcome measures, treatment would most probably need to be initiated in very young patients with TSC when plasticity and developmental speed are at its peak, and mTOR hyperactivation might not yet have caused permanent alterations to the neurodevelopment of the child. Such a window of opportunity for improvement of cognition and behavior might be critical, as shown in animal models of other neurodevelopmental disorders. ${ }^{27}$ As we designed our trial to measure IQ, we could not include patients with TSC below the age of 4 years. Future trials investigating the effect of everolimus on intelligence and other neuropsychological outcome measures should consider focusing on this young patient group. Everolimus has been shown to have an antiepileptic effect in TSC, and we know that improved seizure control in young children is a predictor of better cognitive development. ${ }^{4,6}$ While treatment with everolimus for seizure control can be worthwhile for young patients for that reason, our results suggest no positive effect of everolimus independent of epilepsy in this particular age group.

We showed that everolimus had no significant effect on intelligence, autism, or neuropsychological functioning in children with TSC aged 4-17 years. This is in line with the results of a recently published study examining the effect of everolimus used for 6 months on neuropsychological deficits in children with TSC. Another ongoing trial investigating adolescents and adults (clinicaltrials.gov NCT01954693) will be of interest as a comparison. We stress that everolimus is a validated treatment for SEGA, and shown to be effective in reducing angiomyolipoma and epilepsy in TSC, but should not be prescribed for a potential improvement of intelligence, autistic features, or neuropsychological functions in children aged 4-17 years.

\section{Acknowledgment}

The authors thank all trial participants and their parents and Badies Manai (research nurse) and the Dutch TSC Foundation (Stichting Tubereuze Sclerosis Nederland) for support.

\section{Study funding}

This trial was funded by the Dutch Brain Association (Hersenstichting) and the Sophia Children's Hospital Fund (Stichting Sophia Kinderziekenhuis Fonds, Rotterdam, the Netherlands). Novartis AG provided everolimus and placebo tablets and provided additional financial support. None of the funding sources were involved in trial design, collection of data, analysis, interpretation, or writing of the manuscript. All authors had full access to the study data.

\section{Disclosure}

I. Overwater, A. Rietman, S. Mous, K. Bindels-de Heus, D. Rizopoulos, L. ten Hoopen, T. van der Vaart, F. Jansen, Y. Elgersma, and $\mathrm{H}$. Moll report no disclosures relevant to the manuscript. M. de Wit reports grants from Sophia Foundation (SSWO), non-financial support from Novartis International AG, and grants from Novartis International AG during the conduct of the study; personal fees from Hoffmann-La Roche; and other from Novartis International AG, outside the submitted work. Go to Neurology.org/N for full disclosures.

\section{Publication history}

Received by Neurology October 30, 2018. Accepted in final form March 4, 2019.

Appendix Authors

\begin{tabular}{|c|c|c|c|}
\hline Name & Location & Role & Contribution \\
\hline $\begin{array}{l}\text { Iris E. } \\
\text { Overwater, } \\
\text { MD, PhD }\end{array}$ & $\begin{array}{l}\text { Erasmus Medical } \\
\text { Center-Sophia } \\
\text { Children's Hospital, } \\
\text { Rotterdam, the } \\
\text { Netherlands }\end{array}$ & Author & $\begin{array}{l}\text { Contributed to trial } \\
\text { design, trial } \\
\text { implementation, data } \\
\text { collection, statistical } \\
\text { analysis, and } \\
\text { interpretation of the } \\
\text { data, contributed to } \\
\text { the development of the } \\
\text { manuscript, approved } \\
\text { the final manuscript }\end{array}$ \\
\hline $\begin{array}{l}\text { André B. } \\
\text { Rietman, } \\
\text { MSc }\end{array}$ & $\begin{array}{l}\text { Erasmus MC-Sophia } \\
\text { Children's Hospital, } \\
\text { Rotterdam, the } \\
\text { Netherlands }\end{array}$ & Author & $\begin{array}{l}\text { Contributed to trial } \\
\text { design, trial } \\
\text { implementation, data } \\
\text { collection, statistical } \\
\text { analysis, interpretation } \\
\text { of the data, and } \\
\text { development of the } \\
\text { manuscript, approved } \\
\text { the final manuscript }\end{array}$ \\
\hline
\end{tabular}

Continued 
Appendix (continued)

\begin{tabular}{|c|c|c|c|}
\hline Name & Location & Role & Contribution \\
\hline $\begin{array}{l}\text { Sabine E. } \\
\text { Mous, PhD }\end{array}$ & $\begin{array}{l}\text { Erasmus MC-Sophia } \\
\text { Children's Hospital, } \\
\text { Rotterdam, the } \\
\text { Netherlands }\end{array}$ & Author & $\begin{array}{l}\text { Contributed to data } \\
\text { collection, statistical } \\
\text { analysis, and } \\
\text { interpretation of the } \\
\text { data, contributed to } \\
\text { the development of } \\
\text { the manuscript, } \\
\text { approved the final } \\
\text { manuscript }\end{array}$ \\
\hline
\end{tabular}

\begin{tabular}{|c|c|c|c|}
\hline $\begin{array}{l}\text { Karen } \\
\text { Bindels-de } \\
\text { Heus, MD }\end{array}$ & $\begin{array}{l}\text { Erasmus MC-Sophia } \\
\text { Children's Hospital, } \\
\text { Rotterdam, the } \\
\text { Netherlands }\end{array}$ & Author & $\begin{array}{l}\text { Contributed to trial } \\
\text { design, trial } \\
\text { implementation, data } \\
\text { collection, and } \\
\text { development of the } \\
\text { manuscript, } \\
\text { approved the final } \\
\text { manuscript }\end{array}$ \\
\hline
\end{tabular}

\begin{tabular}{|c|c|c|c|}
\hline $\begin{array}{l}\text { Dimitris } \\
\text { Rizopoulos, } \\
\text { PhD }\end{array}$ & $\begin{array}{l}\text { Erasmus MC, } \\
\text { Rotterdam, the } \\
\text { Netherlands }\end{array}$ & Author & $\begin{array}{l}\text { Contributed to } \\
\text { statistical analysis, } \\
\text { interpretation of the } \\
\text { data, and } \\
\text { development of the } \\
\text { manuscript, } \\
\text { approved the final } \\
\text { manuscript }\end{array}$ \\
\hline
\end{tabular}

\begin{tabular}{|c|c|c|c|}
\hline $\begin{array}{l}\text { Leontine W. } \\
\text { ten } \\
\text { Hoopen, } \\
\text { MD }\end{array}$ & $\begin{array}{l}\text { Erasmus MC-Sophia } \\
\text { Children's Hospital, } \\
\text { Rotterdam, the } \\
\text { Netherlands }\end{array}$ & Author & $\begin{array}{l}\text { Contributed to trial } \\
\text { design, data } \\
\text { collection, and } \\
\text { development of the } \\
\text { manuscript, } \\
\text { approved the final } \\
\text { manuscript }\end{array}$ \\
\hline
\end{tabular}

\begin{tabular}{|c|c|c|c|}
\hline $\begin{array}{l}\text { Thijs van } \\
\text { der Vaart, } \\
\text { MD, PhD }\end{array}$ & $\begin{array}{l}\text { Erasmus MC-Sophia } \\
\text { Children's Hospital, } \\
\text { Rotterdam, the } \\
\text { Netherlands }\end{array}$ & Author & $\begin{array}{l}\text { Contributed to trial } \\
\text { design, statistical } \\
\text { analysis, } \\
\text { interpretation of the } \\
\text { data, and } \\
\text { development of the } \\
\text { manuscript, } \\
\text { approved the final } \\
\text { manuscript }\end{array}$ \\
\hline
\end{tabular}

Floor E. Department of Child Author Contributed to data

Jansen, MD, Neurology, Brain collection and

PhD Centre Rudolf development of the

Magnus, University manuscript,

Medical Centre approved the final

Utrecht, the manuscript

Netherlands

\begin{tabular}{|c|c|c|c|}
\hline $\begin{array}{l}\text { Ype } \\
\text { Elgersma, } \\
\text { PhD }\end{array}$ & $\begin{array}{l}\text { Erasmus MC, } \\
\text { Rotterdam, the } \\
\text { Netherlands }\end{array}$ & Author & $\begin{array}{l}\text { Contributed to trial } \\
\text { design, trial } \\
\text { implementation, } \\
\text { statistical analysis, } \\
\text { interpretation of the } \\
\text { data, and } \\
\text { development of the } \\
\text { manuscript, } \\
\text { approved the final } \\
\text { manuscript }\end{array}$ \\
\hline
\end{tabular}

\begin{tabular}{|c|c|c|c|}
\hline $\begin{array}{l}\text { Henriette } \\
\text { A. Moll, MD, } \\
\text { PhD }\end{array}$ & $\begin{array}{l}\text { Erasmus MC-Sophia } \\
\text { Children's Hospital, } \\
\text { Rotterdam, the } \\
\text { Netherlands }\end{array}$ & Author & $\begin{array}{l}\text { Contributed to trial } \\
\text { design, trial } \\
\text { implementation, } \\
\text { statistical analysis, } \\
\text { interpretation of the } \\
\text { data, and } \\
\text { development of the } \\
\text { manuscript, } \\
\text { approved the final } \\
\text { manuscript }\end{array}$ \\
\hline
\end{tabular}

Appendix (continued)

\begin{tabular}{|c|c|c|c|}
\hline Name & Location & Role & Contribution \\
\hline $\begin{array}{l}\text { Marie- } \\
\text { Claire Y. de } \\
\text { Wit, MD, } \\
\text { PhD }\end{array}$ & $\begin{array}{l}\text { Erasmus MC-Sophia } \\
\text { Children's Hospital, } \\
\text { Rotterdam, the } \\
\text { Netherlands }\end{array}$ & Author & $\begin{array}{l}\text { Contributed to trial } \\
\text { design, trial } \\
\text { implementation, data } \\
\text { collection, statistical } \\
\text { analysis, } \\
\text { interpretation of the } \\
\text { data, and } \\
\text { development of the } \\
\text { manuscript, approved } \\
\text { the final manuscript }\end{array}$ \\
\hline
\end{tabular}

\section{References}

1. Gao XS, Zhang Y, Arrazola P, et al. TSC tumour suppressor proteins antagonize amino-acid-TOR signaling. Nat Cell Biol 2002;4:699-704.

2. Bissler JJ, Kingswood JC, Radzikowska E, et al. Everolimus for angiomyolipoma associated with tuberous sclerosis complex or sporadic lymphangioleiomyomatosis (EXIST-2): a multicentre, randomized, double-blind, placebo-controlled trial. Lancet 2013;381:817-824.

3. Franz DN, Belousova E, Sparagana S, et al. Efficacy and safety of everolimus for subependymal giant cell astrocytomas associated with tuberous sclerosis complex (EXIST-1): a multicentre, randomised, placebo-controlled phase 3 trial. Lancet 2013; 381:125-132.

4. French JA, Lawson JA, Yapici Z, et al. Adjunctive everolimus therapy for treatmentresistant focal-onset seizures associated with tuberous sclerosis (EXIST-3): a phase 3 , randomised, double-blind, placebo-controlled study. Lancet 2016;388:2153-2163.

5. Cusmai R, Moavero R, Bombardieri R, Vigevano F, Curatolo P. Long-term neurological outcome in children with early-onset epilepsy associated with tuberous sclerosis. Epilepsy Behav 2011;22:735-739.

6. Jozwiak S, Kotulska K, Domanska-Pakiela D, et al. Antiepileptic treatment before the onset of seizures reduces epilepsy severity and risk of mental retardation in infants with tuberous sclerosis complex. Eur J Paediatr Neuro 2011;15:424-431.

7. Ehninger D, Han S, Shilyansky C, et al. Reversal of learning deficits in a Tsc2+/mouse model of tuberous sclerosis. Nat Med 2008;14:843-848.

8. Schneider M, de Vries PJ, Schönig K, Rößner V, Waltereit R. mTOR inhibitor reverses autistic-like social deficit behaviours in adult rats with both Tsc2 haploinsufficiency and developmental status epilepticus. Eur Arch Psychiatry Clin Neurosci 2017;267: 455-463.

9. Tsai PT, Hull C, Chu Y, et al. Autistic-like behaviour and cerebellar dysfunction in Purkinje cell Tscl mutant mice. Nature 2012;488:647-651.

10. Cambiaghi M, Cursi M, Magri L, et al. Behavioural and EEG effects of chronic rapamycin treatment in a mouse model of tuberous sclerosis complex. Neuropharmacology 2013;67:1-7.

11. Davies DM, de Vries PJ, Johnson SR, et al. Sirolimus therapy for angiomyolipoma in tuberous sclerosis and sporadic lymphangioleiomyomatosis: a phase 2 trial. Clin Cancer Res 2011;17:4071-4081

12. Kilincaslan A, Kok BE, Tekturk P, Yalcinkaya C, Ozkara C, Yapici Z. Beneficial effects of everolimus on autism and attention-deficit/hyperactivity disorder symptoms in a group of patients with tuberous sclerosis complex. J Child Adolesc Psychopharmacol 2017;27:383-388.

13. Krueger DA, Sadhwani A, Byars AW, et al. Everolimus for treatment of tuberous sclerosis complex-associated neuropsychiatric disorders. Ann Clin Transl Neurol 2017;4:877-887.

14. Overwater IE, Rietman AB, Bindels-de Heus K, et al Sirolimus for epilepsy in children with tuberous sclerosis complex: a randomized controlled trial. Neurology 2016;87: 1011-1018.

15. Krueger DA, Care MM, Holland K, et al. Everolimus for subependymal giant-cell astrocytomas in tuberous sclerosis. N Engl J Med 2010;363:1801-1811.

16. Northrup H, Krueger DA; International Tuberous Sclerosis Complex Consensus G. Tuberous sclerosis complex diagnostic criteria update: recommendations of the 2012 International Tuberous Sclerosis Complex Consensus Conference. Pediatr Neurol 2013;49:243-254.

17. Hendriksen J, Hurks P III. WPPSI-III-NL Wechsler Preschool and Primary Scale of Intelligence, Third Edition; Nederlandstalige bewerking (Dutch version) Afname: en scoringshandleiding (manual). Amsterdam: Pearson; 2009.

18. Kort W, Schittekatte MDP, Verhaeghe P, et al. WISC-III-NL: Wechsler Intelligence Scale for Children, Third Dutch Edition; Handleiding en Verantwoording (manual) Amsterdam: Harcourt Test Publishers \& Nederlands Instituut voor Psychologen; 2005.

19. Beery KE. The Beery-Buktenica Developmental Test of Visual-Motor Integration: Administration, Scoring, and Teaching Manual, 5th ed. Minneapolis: NCS Pearson; 2004.

20. Constantino JN, Gruber CP. Screeningslijst Voor Autismespectrumstoornissen. Amsterdam: Hogrefe Uitgevers B.V.; 2015. 
21. Geurts HM. CCC-2-NL: The Children's Communication Checklist, Second Edition; Nederlandse Versie; Handleiding. Amsterdam: Harcourt Assessment B.V; 2004.

22. Bruni O, Ottaviano S, Guidetti V, et al. The Sleep Disturbance Scale for Children (SDSC) construction and validation of an instrument to evaluate sleep disturbances in childhood and adolescence. J Sleep Res 1996;5:251-261.

23. Dunn W. SP-NL: Sensory Profile, Herziene Nederlandse Editie. Amsterdam: Pearson; 2013.

24. HealthActCHQ. The CHQ Scoring and Interpretation Manual. Cambridge: HealthActCHQ; 2008.
25. Achenbach TM, Rescorla LA. Multicultural Supplement to the Manual for the ASEBA Preschool Forms \& Profiles. Burlington: University of Vermont, Research Center for Children, Youth and Families; 2010.

26. Smidts DP, Huizinga M. BRIEF Executive Functioning Behavior Questionnaire: manual. Amsterdam: Hogrefe; 2009.

27. Silva-Santos S, van Woerden GM, Bruinsma CF, et al. Ube3a reinstatement identifies distinct developmental windows in a murine Angelman syndrome model.J Clin Invest 2015;125:2069-2076. 


\section{Neurology}

\section{A randomized controlled trial with everolimus for $I Q$ and autism in tuberous sclerosis complex}

Iris E. Overwater, André B. Rietman, Sabine E. Mous, et al.

Neurology 2019;93;e200-e209 Published Online before print June 19, 2019

DOI 10.1212/WNL.0000000000007749

This information is current as of June 19, 2019

\section{Updated Information \&} Services

References

Citations

Subspecialty Collections

Permissions \& Licensing

Reprints including high resolution figures, can be found at: http://n.neurology.org/content/93/2/e200.full

This article cites 18 articles, 2 of which you can access for free at: http://n.neurology.org/content/93/2/e200.full\#ref-list-1

This article has been cited by 6 HighWire-hosted articles: http://n.neurology.org/content/93/2/e200.full\#\#otherarticles

This article, along with others on similar topics, appears in the following collection(s):

All CBMRT/Null Hypothesis

http://n.neurology.org/cgi/collection/all_cbmrt_null_hypothesis

Autism

http://n.neurology.org/cgi/collection/autism

Clinical trials Randomized controlled (CONSORT agreement)

http://n.neurology.org/cgi/collection/clinical_trials_randomized_contro

lled_consort_agreement

Mental retardation

http://n.neurology.org/cgi/collection/mental_retardation

Other neurocutaneous disorders

http://n.neurology.org/cgi/collection/other_neurocutaneous_disorders

Information about reproducing this article in parts (figures,tables) or in its entirety can be found online at:

http://www.neurology.org/about/about_the_journal\#permissions

Information about ordering reprints can be found online:

http://n.neurology.org/subscribers/advertise

Neurology ${ }^{\circledR}$ is the official journal of the American Academy of Neurology. Published continuously since 1951, it is now a weekly with 48 issues per year. Copyright () 2019 American Academy of Neurology. All rights reserved. Print ISSN: 0028-3878. Online ISSN: 1526-632X.

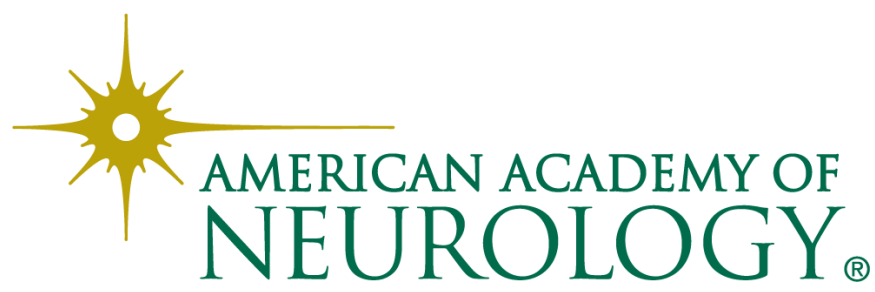

